\title{
RECOVERY ASET DAERAH YANG DIJADIKAN AGUNAN OLEH PIHAK KETIGA DALAM PERJANJIAN KERJASAMA DENGAN BUMD
}

\author{
Khairus Febryan Fitrahady, Ahmad Zuhairi, M. Riadhussyah \\ Fakultas Hukum, Universitas Mataram, Fakultas Syariah, \\ Universitas Islam Negeri Mataram, NTB \\ E-Mail: khairusfebryan@unram.ac.id,zuhairiahmad86@gmail.com, \\ mriadhussyah@uinmataram.ac.id
}

\begin{abstract}
This paper examines the inability of local governments to recover land assets that have been included as capital for regional-owned enterprises (BUMD). The problem arises when the land is used as a $n$ object for collateral by a third party because BUMD is unable to fulfill the achievements in the agreement. This normative research uses a statutory, conceptual and case approach. As a result, the West Lombok Regional Government is still unable to recover regional assets that have been used as collateral by third parties on the basis of a cooperation agreement with BUMD. The land is the capital that is included by the Regional Government to BUMD. Land which becomes the object of capital participation does not automatically transfer to BUMD if the transfer mechanism is not passed and is considered permanent as a regional asset. However, if the Regional Government has approved the land pledge process to the Bank through the general meetings of shareholders (GMS) mechanism, the Government will be very powerless to carry out recovery. However, the regional government could be the losing party if at any time the BUMD cannot fulfill its achievements and the land is auctioned off by the Bank.
\end{abstract}

Key words: Regional Assets, Collateral, Agreement

\begin{abstract}
ABSTRAK
Tulisan ini mengkaji ketidakmampuan Pemerintah Daerah melakukan recovery aset tanah yang telah disertakan sebagai modal kepada BUMD. Permasalahan muncul ketika tanah tersebut dijadikan obyek agunan oleh pihak ketiga karena BUMD tidak mampu memenuhi prestasi dalam perjanjian. Penelitian normatif ini menggunakan pendekatan perundang-undangan, konseptual dan pendekatan kasus. Hasilnya, Pemerintah Daerah Lombok barat hingga saat ini masih tidak mampu untuk melakukan recovery terhadap aset daerah yang sudah dijadikan agunan oleh Pihak ketiga dengan dasar perjanjian kerjasama dengan BUMD. Tanah tersebut merupakan modal yang disertakan oleh Pemerintah Daerah kepada BUMD. Tanah yang menjadi obyek penyertaan modal tersebut tidak otomatis beralih kepada BUMD jika mekanisme pengalihan tidak dilalui dan dianggap tetap sebagai aset daerah. Namun jika Pemerintah Daerah telah menyetujui proses pengagunan tanah tersebut kepada Bank melalui mekanisme RUPS, Pemerintah akan sangat tidak berdaya untuk melakukan recovery. Namun, pemerintah daerah dapat menjadi pihak yang dirugikan jika sewaktu-waktu BUMD tersebut tidak dapat memenuhi prestasi dan tanah tersebut dilelang oleh Bank.
\end{abstract}

Kata Kunci: Aset Daerah, Agunan, Perjanjian 


\section{PENDAHULUAN}

Perkembangan perekonomian di Indonesia secara makro maupun mikro harus didukung oleh instrument kebijakan hukum yang tepat dan efisien, sehingga pengambil kebijakan dan kebijaksanaan dalam memutuskan suatu program baik jangka panjang dan menengah tidak bersumber pada "selera" kekuasaan sebagai otoritas pengambil keputusan menentukan arah pembangunan ekonomi suatu bangsa. Pembatasan periodesasi kekuasaan eksekutif dan legislative sebagai mitra otoritas menjadi alasan mengapa pelaksanaan dari program jangka panjang maupun pendek harus berstandar pada tiga tujuan hukum yakni kepastian yang bermanfaat untuk pembangunan yang berkeadilan.

Pemerintah sebagai otoritas perumus sekaligus pelaksana dari kebijakan tersebut, mulai dari Pemerintah Pusat hingga Pemerintah Daerah secara ideal bersinergi untuk mewujudkan cita-cita konstitusi sebagaimana yang dituangkan dalam alinea keempat Undang-Undang Dasar Negara Republik Indonesia Tahun 1945 yaitu melindungi segenap bangsa Indonesia dan seluruh tumpah darah Indonesia dan untuk memajukan kesejahteraan umum, mencerdaskan kehidupan bangsa, dan ikut melaksanakan ketertiban dunia yang berdasarkan kemerdekaan, perdamaian abadi dan keadilan sosial.

Hal ini berarti bahwa salah satu tujuan didirikannya Negara Indonesia adalah terwujudnya kesejahteraan rakyat. Hal ini juga yang mengindikasikan bahwa Negara Indonesia merupakan negera kesejahteraan. Dalam suatu Negara (hukum) kesejahteraan, Negara atau pemerintah tidak hanya sematamata sebagai penjaga keamanan dan ketertiban masyarakat, tetapi juga sebagai pemikul utama tanggung jawab mewujudkan keadilan sosial, kesejahteraan umum dan sebesar-besar kemakmuran rakyat. ${ }^{1}$

Sinergisitas tersebut terlebih sangat penting sejak otonomi daerah mulai diakui pasca amandemen kedua yang kemudian dituangkan dalam Pasal 18. 18A, dan 18 B yang substansinya secara tegas memberikan pengakuan tentang keberadaan Pemerintah Daerah baik Provinsi dan Kabupaten/Kota dengan asas desentralisasi yang melahirkan otonomi daerah pada masing-masing daerah otonom. Kemudian selain dalam konstitusi, ditegaskan kembali dalam Undang-Undang Nomor 32 tahun 1999 yang kemudian disusul dan digantikan oleh Undang-Undang Nomor 32 tahun 2004 kemudian disusul dengan Undang-Undang Nomor 23 Tahun 2014tentang Pemerintahan Daerah yang secara subtansial memberikan otonomi kepada daerah provinsi dan kabupaten serta pemerintahan kota suatu kewenangan serta otonomi yang lebih luas dibandingkan era sebelumnya. Dengan diberlakukannya Undang-Undang tersebut, maka pemerintah daerah memiliki wewenang untuk mengatur pembangunan infrastruktur, 
ekonomi, pendidikan dan bidang-bidang lainnya dengan pembatasan kewenangan melalui Undang-Undang. Menurut pandangan Mudrajad Kuncoro salah satu tujuan kebijakan desentralisasi dan otonomi daerah adalah untuk menjadikan pemerintah lebih dekat dengan rakyatnya, sehingga pemerintah dapat dilakukan dengan lebih efisien dan efektif. Sistem desentralisasi tetap diterapkan untuk memudahkan koordinasi kekuasaan dan Pemerintah, disamping untuk lebih mengakomodasi keberagaman wilayah Indonesia. $^{2}$

Dalam rangka pembangunan daerah dibidang ekonomi, Pemerintah Daerah dapat melakukan kegiatan usaha melalui pembentukan Badan Usaha Milik Daerah (BUMD) sebagaimana yang diatur dalam Pasal 331 Undang-Undang Nomor 23 Tahun 2014 bahwa Pemerintah daerah dapat mendirikan BUMD dengan bentuk Perusahaan Umum Daerah (PERUMDA) dan Perusahaan Perseroan Daerah (PERSERODA). Dalam Peraturan Pemerintah Nomor 54 Tahun 2017 tentang Badan Usaha Milik Daerah dipertegas tentang modal dari PERUMDA yang tidak terbagi atas saham sedangkan BUMD dengan PERSERODA modal terbagi atas saham yang minimal $51 \%$ oleh satu daerah.

Badan Usaha Milik Daerah baik sebagai PERUMDA atau PERSERODA harus berstatus sebagai Badan Hukum. Dengan status sebagai Badan Hukum, maka permodalan dari Persuaahaan Daerah tidak dapat sepenuhnya bergantung pada kekayaan daerah yang dipisahkan, melainkan dapat pula mencari sumber-sumber lain berdasarkan konsep bisnis dan tunduk pada hukum keperdataan. Dengan sistem ini maka peningkatan kesejahteraan masyarakat dan pertumbuhan ekonomi daerah akan dapat mengurangi beban Anggaran Pendapatan dan Belanja Daerah. ${ }^{3}$

Seiring dengan perkembangan zaman serta dalam rangka menjamin kepastian dan penegakan hukum mengingat terjadinya dualisme pengaturan pada Perseroan Terbatas yangselamainidiaturdalamKUHD(Staatsblad Tahun 1847 Nomor 23) dan Ordonansi Maskapai Andil Indonesia (Ordonnantie op de Indonesische Maatschappij op Aandeelen, Staatsblad 1939: 569 jo.717) Pemerintah menerbitkan Undang-Undang Nomor 1 Tahun 1995 tentang Perseroan Terbatas sebagai penganti Buku Kesatu Titel Ketiga Bagian Ketiga Pasal 36 sampai dengan Pasal 56 Kitab Undang-undang Hukum Dagang (Wetboek van Koophandel, Staatsblad 1847: 23) yang mengatur mengenai Perseroan Terbatas berikut segala perubahannya, terakhir dengan Undang-undang Nomor 4 Tahun 1971 dan Ordonansi Maskapai Andil Indonesia (Ordonnantie op de Indonesische Maatschappij op Aandeelen, Staatsblad 1939: 569 jo.717). ${ }^{4}$ Kemudian kini disempurnakan

2 Tjip Ismail, "Implementasi Otonomi Daerah Terhadap Paradigma Pajak Daerah di Indonesia", Desertasi Program Pascasarjana Doktor Ilmu Hukum, (Jakarta: Universitas Indonesia, 2005), hlm.3

3 Teuku Ahmad Yani, "Peran Badan Usaha Milik Daerah Dalam Meningkatkan Kesejahteraan Masyarakat (Studi Pembentukan Perusahaan Daerah Di Aceh)", Kanun Jurnal Ilmu Hukum No 56, (April 2012): 127

4 Safri Nugraha, Privatisasi BUMD Dalam Upaya Meningkatkan Kinerja, (Jakarta : BPHN- Departemen Kehakiman, 1996), hlm. 36 
denganUndang-Undang Nomor40 Tahun 2007 tentang Perseroan Terbatas, yang kemudian menjadi dasar hukum pengelolaan BUMD dari aspek Badan Hukum, sedangkan dasar hukum Badan usahanya mengikuti bentuk dari badan usaha BUMD yang diamanatkan dalam peraturan Daerah mengenai bentuk dan kegiatan Usaha dari BUMD. Misalkan BUMD yang berbentuk Bank, maka peraturan dan mekanisme perizinan dalam Undang-Undang Perbankan menjadi acuan dalam menjalankan kegiatan usaha dengan Perseroran Terbatas (PT) sebagai badan hukum.

Pemerintah Daerah sebagai pemilik modal dari Badan Usaha Milik Daerah sebagaimana dijelaskan diatas, dapat melakukan penyertaan modal kepada BUMD yang dibentuk untuk kepentingan investasi dalam bentuk uang maupun barang milik daerah, dengan syarat BUMD tersebut dibentuk melalui mekanisme Peraturan Daerah dan Penyertaan Modal diatur juga dalam Peraturan Daerah. Hal tersebut diatur dalam Pasal 41 ayat (5) Undang-Undang Nomor 1 Tahun 2014 tentang Perbendaharaan Negara.

Dalam Undang-Undang Nomor 23 Tahun 2014 dijelaskan dalam ketentuan Umum bahwa BUMD merupakan badan usaha yang seluruh atau sebagian besar modalnya dimiliki oleh Daerah, dan modal penyertaan dari Pemerintah Daerah kepada BUMD berasal dari Kekayaan Daerah yang dipisahkan. Konsep tersebut sama dengan konsep penyertaan modal dari Negara kepada BUMN sebagaimana yang diatur dalam Undang-Undang 19 Tahun 2003 tentang Badan Usaha Milik Negara.

Terdapat berbagai pendapat terkait dengan konsep harta kekayaan yang dipisahkan, seperti pendapat Prof. Erman Rajaguguk pada Konferensi Nasional dengan Tajuk Permasalahan Hukum Keuangan Negara Ditinjau dari Ketentuan Perundang-Undangan yang Berlaku, Teori dan Praktik Bernegara di Indonesia dan dikutip oleh laman Hukum Online tanggal 31 Oktober 2012 dengan judul Kekayaan BUMN bukan merupakan kekayaan Negara, dimana sesuai dengan Undang-Undang Perseoran Terbatas, BUMN mendapat pengesahan Badan Hukum dari Menteri Hukum dan HAM, sehingga tidak dapat dikatakan kekayaan BUMN merupakan Kekayaan Negara. ${ }^{5}$

Hal yang berbeda jika kita temukan dalam Undang-Undang Nomor 31 Tahun 1999 sebagaimana yang telah diubah oleh UndangUndang Nomor 20 Tahun 2001 tentang Tindak Pidana Korupsi menjelaskan bahwa seluruh kekayaan negara dalam bentuk apapun, baik dipisahkan atau tidak dipisahkan merupakan bagian dari keuangan negara. Sehingga hal tersebut menjadi perdebatan dan muncul sebuah persoalan apakah kerugian yang diderita BUMD/BUMD merupakan kerugian Negara? Isu tersebut menjadi debatable jika hanya melihat dari satu aspek sisi saja.

Seperti halnya kasus yang terjadi di salah satu Kabupaten di Nusa Tenggara Barat yakni Kabupaten Lombok Barat, dimana 
Lombok Barat memiliki beberapa Badan Usaha Milik Daerah yang diharapkan mampu menambah pendapatan daerah dari sektor selain pajak. Salah satu BUMD yang dimiliki adalah PT. Patuh Patut Patju atau yang kemudian disingkat dan dikenal sebagai PT. TRIPAT. Pembentukan PT. Tripat ini melalui mekanisme Peraturan Daerah Nomor 7 Tahun 2010 tentang Perubahan Bentuk Badan Hukum Perusahaan Daerah (PD) Patuh Patut Patju menjadi Perseroan Terbatas (PT) Patuh Patut Patju, dimana dalam Pasal 6 disebutkan bahwa Perusahaan tersebut bergerak dalam bidang usaha usaha jasa, traiding, Developer, kontraktor, industri, export import dan kelompok bidang usaha lainnya yang tidak bertentangan dengan peraturan perundangundangan yang berlaku. Dalam Perda mengenai perubahan status perusahaan daerah tersebut, disebutkan bahwa penyertaan modal dari Pemerintah Daerah berupa uang sebesar Rp. 360.000.000,- (tiga ratus enam puluh juta rupiah) dan tanah dengan luas 8 ha (hektare), yang kemudian penyertaan dalam bentuk tanah/aset ditambah menjadi 8,4 ha (hektare) berdasarkan Perda Kabupaten Lombok Barat Nomor 8 Tahun 2010 tentang Penyertaan Modal Pemerintah Kabupaten Lombok Barat Kepada Badan Usaha Milik Daerah Dan Badan Hukum Lainnya.

Dalam perjalanan bisnisnya, BUMD tersebut melakukan kerjasama operasional dengan Pihak Ketiga melalui perjanjian untuk melakukan pengembangan terhadap usahanya, dimana belakangan tanah yang menjadi modal tersebut diagunkan di Bank, dan diindikasikan terjadi tindak pidana korupsi sebagaimana yang diberitakan oleh beberapa media lokal salah satunya lombok post 26 Maret $2019 .{ }^{6}$ Yang menjadi permasalahan adalah tanah tersebut berasal dari aset daerah yang telah disertakan kepada Badan usaha Milik Daerah. Dalam kasus ini akan menjadi dilematis terkait dengan kemampuan pemerintah daerah yang akan melakukan rocevery restorasi terhadap aset daerah yang statusnya bisa saja dilakukan lelang karena telah dijadikan sebagai agunan di Bank.

\section{METODE PENELITIAN}

Adapun metode penelitian yang digunakan dalam tulisan ini yaitu penelitian hukum normatif, mengkaji dalam perspektif norma hukum dengan menggunakan metode pendekatan peraturan perundang-undangan dan pendekatan konseptual berkaitan dengan permasalahan yang dikaji.

\section{PEMBAHASAN}

\section{A. Konsep Pemisahan Kekayaan Perusahaan Perseroan Daerah}

Badan Usaha Milik Daaerah selanjutnya disingkat dengan BUMD sesuai ketentuan Pasal 402 ayat (2) Undang-Undang 23 Tahun 2014 tentang Pemerintahan Daerah

6 Lombok Post Online, "Kasus LCC semakin terang”, https://www.lombokpost.net/2019/03/26/kasus-lccmakin-terang/, diakses 26 maret 2019 
wajib menyesuaikan bentuk hukum menjadi Perusahaan Umum Daerah (Perumda) atau Perseroan Daerah (Perseroda) sesuai kepemilikan modal/sahamnya. Jika modalnya dimiliki oleh satu Daerah dan tidak terbagi atas saham maka berbentuk Perusahaan Umum Daerah (Perumda) atau jika berbentuk perseroan terbatas yang modalnya terbagi dalam saham yang seluruhnya atau paling sedikit 51\% (lima puluh satu persen) sahamnya dimiliki oleh satu daerah maka berbentuk Perusahaan Perseroan Daerah (Perseroda). Dalam Pasal 339 Ayat (1) Undang-Undang No. 23 Tahun 2014 tentang Pemerintahan Daerah ditegaskan bahwa Perusahaan Perseroan Daerah setelah ditetapkan dengan Perda sebagaimana dimaksud dalam Pasal 331 ayat (2), pembentukan badan hukumnya dilakukan berdasarkan ketentuan peraturan perundang-undangan mengenai perseroan terbatas. Lebih lanjut, pada saat dilakukannya proses mengagunkan kekayaan perseroan, seperti contoh diatas pada kasus PT. Tripat, dimana BUMD tersebut masih berstatus hukum sebagai Perseroan Terbatas (PT) dan apabila melaksanakan perubahan bentuk hukum sesuai Undang-Undang No. 23 Tahun 2014 tentang Pemerintahan Daerah, akan lebih tepat jika mengarah pada bentuk hukum Perseroda.

Melihat ketentuan Pasal tersebut di atas, konsekuensi memilih Perusahaan perseroan Daerah artinya menggunakan Perseoran
Terbatas yang di mana Badan Usaha yang Berbadan Hukum yang bertujuan untuk mencari Laba. Menurut teori fiksi yang pelopori oleh Von Savigny adalah bahwa subyek hukum terdiri dari dua yaitu orang (naturlijk Persoon) dan Badan Hukum (recht person). Badan hukum menurut teori fiksi dipersamakan dengan orang yang dapat menyandang hak dan kewajiban sendiri serta mempunyai kekayaan yang terpisah.

Pendapat yang sama juga diungkapkan oleh Henery Hansmann dan Reinier Kraakman yang dikutip oleh Yudho Taruno Muryanto menyatakan bahwa badan hukum itu seperti halnya manusia terutama dalam hal yang berkaitan dengan aset yang mempunyai ciri di antaranya; adanya pemisahan aset, yang memberikan keuntungan bagi badan hukum tersebut, penetapan pemisahaan terhadap aset dilakukan dengan adanya ketentuan hukum organisasi (perusahaan), dan hak milik (property) merpakan kontribusi yang sensual yang diberikan hukum organisasi (perusahaan) pada kegiatan komersial. ${ }^{7}$

Entity Theory juga mempunyai pandangan bahwa Badan Hukum sebagai suatu entitas bisnis. Teori ini mengasumsikan bahwa terjadi pemisahaan antara kepentingan pribadi pemilik equitas (owners) dan entitas bisnisnya (Perseroan). Teori ini pertama kali diadopsi dari hukum Inggris yang didasarkan pada teori konsesi. Pemerintah setempat memperlakukan sebuah perusahaan sebagai sebuah entitas yang 
memisahkan antara kepentingan pribadi dan perusahaan. Selama periode ini, perusahaan menerima banyak tugas dari Negara untuk melaksanakan tujuan tertentu, dan sebagai konsekuensinya, perusahaan menjadi lebih banyak terkait dengan sektor-sektor publik.

Teori ini mengajarkan bahwa sebuah entitas bisnis menjadi suatu bentuk personifikasi yang memiliki karakter tersendiri dan sama sekali tidak identik dengan pemilik. Bahkan suatu perusahaan dianggap memiliki eksistensi tersendiri yang lepas dari interaksi langsung dengan pemiliknya. Pemilik equitas, kreditor, dan pemegang saham memiliki hak yang berbeda berkaitan dengan penghasilan, risiko, kendali,dan likuidasi. Pendapatan yang diperoleh adalah hak entitas yang kemudian didistribusikan ke pemegang saham sebagai dividen. Profit yang tidak didistribusikan dianggap sebagai hak entitas bisnis.

Akuntabilitas terhadap pemegang saham dilaksanakan dengan cara menilai kinerja operasi dankeuangan perusahaan. Entity theory melahirkan agency theory dan stwadership theory yang mempengaruhi pembentukan struktur corporate governance. ${ }^{8}$ Ridwan Khairandy mengatakan bahwa Badan hukum adalah rekayasa manusia untuk membentuk suatu suatu bandan yang memiliki status, kedudukan, kewenangan yang sama seperti manusia. Oleh karena badan ini adalah hasil rekayasa manusia, maka badan ini disebut sebagai artificial person. Sehingga di dalam hukum, subyek hukum disandang oleh oleh manusia dan badan hukum.

Oleh karena badan hukum adalah subyek hukum, maka ia merupakan badan independen atau mandiri dari pendiri, anggota, atau penanam modal tersebut. Badan ini dapat melakukan kegiatan bisnis atau nama dirinya sendiri seperti manusia. Bisinis yang dijalankan, kekayaan yang dikuasai, kontrak yang dibuat semua atas nama badan itu sendiri. Badan ini seperti halnya manusia memiliki kewajiban-kewajiban hukum, seprti membayar pajak dan menjaukan izin kegiatan bisnis atas nama dirinya sendiri. ${ }^{9}$

Sifat terbatasnya tanggung jawab secara singkat merupakan pernyataan dari prinsip bahwa pemegang saham atau para anggota tidak bertanggung jawab secara pribadi atas kewajiban perusahaan sebagai badan hukum yang kekayaannya terpisah dari pemegang sahamnya atau anggotanya. Prinsip continuity of existence menegaskan tentang pemisahan kekayaan korporasi dengan pemiliknya. Badan hukum itu sendiri tidak dipengaruhi oleh kematian atapun pailitnya pemegang saham. Sebagai akibatnya, saham-saham perusahaan diperdagankan secara bebas.

Khairandy mencontohkan bahwa Perseroan Terbatas adalah badan usaha yang berbadan hukum yang mempunyai ciri substantive yang melekat pada dirinya yaitu; ${ }^{10}$

8 Ridwan Khairandy, Hukum Perseoran Terbatas, (Yogyakarta: FH UII Press, 2014), hlm. 182-183

9 Ridwan Khairandy, Pokok-Pokok Hukum Dagang Indonesia, (Yogyakarta: FH UII Press, 2014), hlm. 29-30 10 Ibid, hlm. 31 
1. Terbatasnya tanggung jawab

Pada dasarnya, para pendiri atau pemegang saham atau anggota suatu korporasi tidak bertanggung jawab secara pribadi terhadap kerugian atau utang korporasi. Tanggung jawab pemegang saham hanya sebatas jumlah maksimum nominal saham yang ia kuasai. Selebihnya, ia tidak bertanggung jawab.

2. Perpetual Succession

Sebagai sebuah korporasi yang eksis atas haknya sendiri, perubahan keanggotaan tidak memiliki akibat atas status atau eksistensinya. Bahkan, dalam konteks PT, pemegang saham dapat mengalihkan saham yang ia miliki kepada pihak ketiga. Pengalihan tidak menimbulkan masalah kelangsungan perseroan yang bersangkutan. Bahkan, bagi PT yang masuk dalam kategori PT Terbuka dan sahamnya terdaftar di suatu bursa efek (listed), terdapat kebebasan untuk mengalihkan saham tersebut.

3. Memiliki kekayaan sendiri

Semua kekayaan yang ada dimiliki oleh badan itu sendiri, tidak dimiliki oleh anggota atau pemegang saham. Ini adalah suatu kelebihan utama badan hukum. Dengan demikian, kepemilikan kekayaan tidak didasarkan pada anggota atau pemegang saham.

4. Memiliki kewenangan Kontraktual serta Dapat menuntut dan dapat dituntut ata nama dirinya sendiri.
Badan hukum sebagai subyek hukum diperlakukan seperti manusia yang memiliki kewenangan kontraktual. Badan itu dapat mengadakan hubungan kontraktual atas nama dirinya sendiri. Sebagai subyek hukum, badan hukum dapat dituntut dan menuntut di hadapan pengadilan.

Melihat konsep badan hukum sebagaimana dikemukakan oleh para ahli di atas artinya bahwa setiap kekayaan yang sudah ditempatkan ke Badan Hukum merupakan kekayaan yang terpisah dari pemiliknya dan dimiliki oleh badan hukum tersebut secara mandiri. Jika seseorang menempatkan modal di suatu badan hukum perseroan maka modal tersebut sudah terpisah dari kekayaan pemilik modal tersebut, sehingga jika nanti badan hukum perseroan tersebut mengalami bangkarut atau pailit maka pemilik modal itu tidak sampai melibatkan harta pribadinya, tanggung jawabnya hanya sebatas modal yang disetorkan. Bagaimana jika daerah melepas modal terhadap suatu badan hukum perseoran daerah? berdasarkan konsep badan hukum, maka konsekuensinya adalah modal daerah tersebut sudah terpisah, artinya modal daerah sudah tidak lagi menjadi uangnya secara utuh tapi sudah beralih ke perusahaan daerah tersebut. Itulah konsep badan hukum, jadi dia mempunyai hak dan kewajiban tersendiri dan mempunyai harta kekayaan tersendiri. Pemilik modal/saham hanya bisa mengambil bagian dividen setelah terkumpul dalam badan hukum kemudian dishare semuda dividen ke 
pemegang saham pada waktu Rapat Umum Pemegang Saham. Dividen yang tidak diambil maka itu menjadi kekayaan dari badan hukum tersebut.

Badan Usaha Milik Daerah memiliki karakteristik yang berbeda dengan Badan Usaha Milik Negara, sekalipun modal yang dimiliki merupakan penyertaan dari Negara. Kepala Daerah menjadi pemegang saham dalam Rapat Umum Pemegang Saham yang berhak memberikan masukan dalam penentuan pengambilan kebijakan oleh perusahaan, dimana dalam jabatannya sebagai kepala daerah, mereka memiliki kewenangan menjalankan kekuasaan pengelolaan keuangan daerah sebagaimana yang diatur dalam Pasal 2 Peraturan Pemerintah Nomor 54 Tahun 2017 tentang Badan Usaha Milik Daerah yang kemudian akan dipertanggungjawabkan dihadapan Dewan Perwakilan Rakyat Daerah setempat.

Dari aspek governance, misalnya, institusi BUMD masih diperlakukan sama dengan institusipemerintah. Padahal,BUMDbukanlah institusi pemerintah. Implikasinya, berbagai kewajiban yang melekat pada pemerintah, melekat pula pada BUMD. Sebagai contoh, BUMD masih harus mengikuti ketentuan pengadaan barang yang diberlakukan di pemerintahan, yang semestinya tidak perlu karena BUMD adalah perusahaan. BUMD juga masih harus menjalani pemeriksaan atas laporan keuangan oleh Badan Pemeriksa
Keuangan (BPK) karena alasan keuangan negara. Padahal, sebagai perseroan terbatas (PT), BUMD juga diperiksa kantor akuntan publik (KAP) yang independen. Dan perlu dicatat, pemeriksaan laporan keuangan oleh BPK ini, sudah tak berlaku lagi di BUMN. Tidak adanya equal treatment bagi BUMD (yaitu sebagai perusahaan yang dituntut harus laba), menyebabkan BUMD tidak dapat bersaing secara seimbang dengan BUMN dan swasta yang lebih lincah. BUMD juga menghadapi masalah minimnya permodalan akibat kurangnya perhatian dari pemilik (dalam hal ini pemerintah daerah/Pemda). Kalaupun ada Pemda yang memiliki perhatian lebih terhadap aspek permodalan BUMN ini, itu pun masih harus menghadapi ganjalan politik, karena interpretasi yang keliru dari para politisi DPRD dalam memahami peraturan. ${ }^{11}$

\section{B. Menguji Asas Kebebasan Berkontrak (Freedom Of Contract) Sebagai Dasar Perusahaan Daerah Dan Pihak Ketiga Menjaminkan Aset Daerah}

Hukum mengakui otonomi individu untuk dalam kebebasan penuh membuat suatu kontrak; dengan siapa ia hendak membuat kontrak, dan juga kebebasannya untuk menentukan sendiri muatan isi kontrak. Kebebasan berkontrak akan dibatasi bila pelaksanaan kebebasan berkontrak dalam 
situasi konkret ternyata bertentangan dengan kepentingan dalam tataran yang lebih tinggi. Kebabsan individu untuk membuat kontrak untuk sebagian juga dibatasi oleh perkembangan masyarakat, misalnya kolektivitasi. Pada umumnya, UndangUndang memandang penting (prinsip) kebebasan untuk melakukan perbuatan. Tidaklah selamanya mudah untuk menetapkan apakah suatu ketentuan bersifat memaksa atau sekedar mengatur dan melengkapi. Dalam rangka itu, maka harus diperhatikan terutama maksud pembuat undang-undang serta maksud dan tujuan kontrak.

Berdasarkan ketetuan Pasal 3: 40 BW, maka suatu tindakan atau perbuatan hukum akan dilarang berkenaan dengan tiga hal saja, yakni bila perbuatan tersebut bertentangan dengan undang-undang, kesusilaan, atau ketertiban umum ruang lingkup keberlakuan ketentuan Pasal 3: 40 ayat (2) dan (3) BW terbatas karena dua alasan. Dalam pembatasan pertama: Undang-Undang sendiri dapat menetapkan suatu tindakan hukum terlarang dan mengaitkan ancaman sanksi terhadapnya. Ancaman sanksi yang tercantum didalam ketentuan Pasal 3: 40 BW karena itu menjadi tidak perlu, sebab sanksi serta-merta muncul dari ketentuan larangan yang dimuat didalam undang-undang. Batasan kedua terhadap lingkup keberlakukan ketentuan Pasal 3: 40 ayat (2) dan (3) termaktub di dalam ketentuan itu sendiri. Di dalam artian formal harus merupakan hukum yang bersifat memaksa (imperatif) dan melarang dilakukan (dimunculkannya) suatu perbuatan hukum. Di samping itu, ketentuan ayat (3) menetapkan bahwa ketentuan undang-undang tersebut harus berkenaan dengan keabsahan dari tindakan hukum yang melanggar ketentuan tersebut. Jika syarat-syarat diatas tidak terpenuhi, tidak mungkin ada persoalan tuntutan kebatalan (demi hukum) atau dapat dibatalkan atas dasar ketentuan Pasal 3: 40 ayat (2) dan (3) BW. Didalam praktik, pembedaan antara pelaksanaan dan substansi suatu perbuatan hukum tidaklah selalu mudah dilakukan. Juga tidak selamanya jelas apakah aturan perundang-undangan tersebut melarang pelaksanaan dari suatu tindakan hukum apakah yang terlarang adalah substansi dari perbuatan tersebut. Pembedaan ini penting karena pada prinsipnya ayat (1) hanya membuka pilihan antara kebatalan (demi hukum) atau keabsahan, sedangkan ayat (2) dan (3) memberikan pilihan yang lebih ternuansa; kebatalan (demi hukum), dapat dibatalkan atau absah. Adalah tugas dari hakim yang berhadapan dengan situasi konkret untuk memberikan pertimbangan dan putusan.

Masalah legitimasi (pembenaran hukum) dari daya mengikat kontrak yang sebenarnya menyoal secara dasariah kekuatan mengikat kontrak. Dengan kata lain, apa yang harus kita anggap penting dalam ihwal pembentukan dan penafsiran dari aturanaturan uang mengatur keberlakuan kontrak. Daya mengikat perjanjian beranjak dari BW-Bld (lama) yang pada saat ini telah 
diperbaharui dan diundangkan pada tahun 1992) dilegitimasi atas dasar pertimbangan bahwa yang tersebut dilandaskan pada kesepakatan para pihak terkait, namun demikian, di dalam ketentuan Pasal 1357 - 1364 BW-Bld. (Lama) atau Pasal 1321 1328 KUHPdt. Indon., tidak dijelaskan apa yang dimaksud dengan kesepakatan tersebut, bahkan juga cara bagaimana ksepakatan tersebut harus terwujud; hanya disebutkan kondisi-kondisi yang membuat perjanjian dapat dibatalkan (Vernietigbar). Di belanda, pandangan umum yang berlaku mencari inti dari syarat kesepakatan (konsensus) pada latar belakang kejiwaan dari para pihak; pernyataan kehendak dari para pihak atau kehendak yang diwujudnyatakan (geopenbaarde wil) serta dilandaskan pada kepercayaan atau harapan yang wajar (gerechtvaardidgd vertrouwen) terbentuknya suatu perjanjian (Pasal 3;33 dan 3;35 BW) di dalam BW, kesepakatan (toestemming) tidak lagi disebutkan sebagai syarat terjadniya perjanjian. Namun, disebutkan bahwa kesepakatan akan terbentuk melalui pernyataan kehendak yang saling terkait dan berkesesuaian. ${ }^{12}$

Penerapan asas kebebasan berkontrak yang sangat dominan dalam hukum kontrak pada abad kesembilan belas yang tidak memberikan tempat pada asas penyalahgunaan keadaan sebelumnya, kini telah bergeser sedemikian rupa. Dikembangkannya asas itikad baik (goeder trouw) dan munculnya ajaran penyalahgunaan keadaan (Misbruik Van Omstandigheiden atau Undue Influence) telah memungkinkan pihak ketiga, yakni hakim untuk berperan mencampuri pelaksanaan perjanjian. $^{13}$

Lembaga hukum (Rechstfiguur) penyalahgunaan keadaan (Misbruik Van Omstandigheiden atau Undue Influence) merupakan bentuk cacat kehendak yang baru dalam sistem hukum kontrak Belanda. Hukum kontrak Belanda mengadopsi lembaga penyalahgunaan keadaan ini dari hukum Inggris. ${ }^{14}$

Di negara-negara common law, doktrin Penyalahgunaan Keadaan (misbruik van omstandigheiden) sudah lama diterima. Doktrin ini dikenal dalam doktrin equity. Equity adalah doktrin yang memperbolehkan hakim untuk membuat suatu putusan yang didasarkan atas kepatutan, persamaan, hak moral dan hukum alam. Doktrin ini mulai berkembang pada abad 19 (sembilan belas), yang sebenarnya merupakan perluasan dari Power of Equity bagi pengadilan untuk mengintervensi suatu perjanjian yang di dalamnya terdapat suatu penyalahgunaan posisi yang tidak seimbang diantara para pihak. ${ }^{15}$

12 Herlien Budiono, “Asas Keseimbangan bagi Hikum Perjanjian Indonesia (Hukum Perjanjian Berlandaskan Asas-Asas Wigati Indonesia)", (Bandung: PT. Citra Aditya Bakti, 2015), hlm. 4-5

13 Latifa Mustafida, "Penerapan Doktrin Misbruik Van Omstandigheiden terhadap Pembatalan Akta Notaris Berdasarkan Putusan Pengadilan”, Jurnal Lex Renaissance No. 1, Vol.2, (Januari 2017): 65

14 J.M Van Dunne dalam Ridwan Khairandy, Hukum Kontrak Indonesia (Dalam Perspektif Perbandingan (Bagian Pertama), (Yogyakarta: FH UII Press, 2013), hlm. 227

15 Ridwan Khairandy, Hukum Kontrak Indonesia Dalam Perspektif Perbandingan (Bagian Pertama), (Yogyakarta: FH UII Press, 2013), hlm. 227 
Sebelumnya, dalam judul, penulis menggunakan istilah recovery yang menurut kamus bahasa inggris berarti pemulihan, sedangkan dalam kamus besar bahasa Indonesia $(\mathrm{KBBI})$ pemulihan menggunakan istilah restorasi yang kemudian memilki makna yang sama dengan recovery. Recovery disini dimaksudkan bagaimana usaha dan kemampuan Pemerintah Daerah melakukan pemulihan kembali terhadap aset daerah yang telah dijadikan obyek penyertaan modal kepada Badan Usaha Milik Daerah.

Merujuk pada contoh kasus sebagaimana yang diuraikan dalam pendahuluan diatas mengenai suatu aset daerah yang dijadikan obyek penyertaan modal kepada Badan Usaha Milik Daerah. Penyertaan modal kepada BUMD tersebut merupakan salah satu bentuk wujud dari Hak Otonomi yang dimiliki oleh Daerah dalam menjalankan roda pemerintahan.

Otonomi daerah diberikan kepada pemerintah daerah agar dapat mengatur dan mengurus sendiri urusan pemerintahan menurut asas otonomi dan tugas pembantuan. Bahkan otonomi daerah diberikan seluasluasnya untuk mempercepat terwujudnya kesejahteraan masyarakat, selain juga untuk meningkatkan daya saing daerah dalam sistem Negara Kesatuan Republik Indonesia. Untuk itu pemerintah daerah dapat mengatur sendiri beberapa bidang kehidupan di daerahnya, diantaranya bidang sosial, budaya, kesehatan, pendidikan, ekonomi, dan sebagainya. ${ }^{16}$

Barang Milik Daerah adalah semua barang yang dibeli atau diperoleh atas beban APBD atau berasal dari perolehan lainnya yang sah sebagaimana dijelaskan dalam Undang-Undang Nomor 1 Tahun 2014 tentang Perbendaharaan negara. Barang Milik Daerah dapat dijadikan sebagai obyek permodalan kepada BUMD sebagaimana disebutkan dalam Pasal 21 ayat 2 Peraturan Pemerintah Nomor 54 Tahun 2017 tentang Badan Usaha Milik Daerah.

Pasal 49 ayat (5) Undang-Undang Nomor 1 Tahun 2014 juga tidak membenarkan jika Barang Milik Daerah/Aset Daerah digadaikan atau dijadikan agunan yang berbunyi sebagai berikut: "Barang milik negara/daerah dilarang digadaikan atau dijadikan jaminan untuk mendapatkan pinjaman". Dalam aturan terebut jelas, bahwa aset daerah/barang milik daerah tidak dapat dijadikan sebagai obyek jaminan atau digadaikan. Dengan demikian larangan tersebut berlaku bagi barang yang berstatus sebagai aset daerah/barang milik daerah. Namun demikian, dalam konteks penyertaan modal, status aset daerah/barang milik daerah perlu kembali dicermati secara mendalam. Hal ini karena sesuai Peraturan Menteri Dalam Negeri Nomor 19 tahun 2016 tentang Pedoman Pengelolaan Barang Milik Daerah, Penyertaan Modal daerah merupakan salah satu bentuk pemindahtanganan barang 
milik daerah dan setelah serah terima barang akan diikuti dengan proses penghapusan barang milik daerah dari daftar barang milik daerah.

Jika dikaitkan dengan pengelolaan aset daerah yang telah disertakan kedalam modal Badan Usaha Miliki Daerah dan merujuk pada Peraturan Mendagri tersebut diatas, maka seharusnya aset/barang milik daerah tersebut dengan segala proses pengalihannya menjadi milik Badan Usaha Milik Daerah, sehingga aset tersebut dapat dimanfaatkan sebagai obyek kerjasama dengan pihak ketiga atau didayagunakan sesuai peraturan perundangundangan dan prinsip good corporate governance. Peraturan Menteri Dalam Negeri tersebut berpeluang melepaskan daya Pemerintah Daerah sewaktu-waktu mengambil kembali/melakukan recovery jika aset tersebut telah menjadi modal/milik Badan Usaha Milik Daerah.

Dalam Peraturan Menteri Dalam Negeri 118 Tahun 2018 tentang Rencana Bisnis, Rencana Kerja Dan Anggaran, Kerja Sama, Pelaporan dan Evaluasi Badan Usaha Milik Daerah menyebutkan bahwa BUMD dalam melakukan Kerjasama dengan pihak lain bisa dalam bentuk operasi (joint operation), pendayagunaan ekuitas (joint venture), dan kerjasama lainnya sesuai dengan ketentuan peraturan perundang-undangan.

Kerjasama antara Badan Usaha Milik Daerah dengan pihak ketiga tentunya berdasarkan Peraturan Pemerintah Nomor 54 Tahun 2017 tentang Badan Usaha Milik
Daerah, Peraturan Menteri Dalam Negeri Nomor 118 Tahun 2018 tentang Rencana Bisnis, Rencana Kerja Dan Anggaran, Kerja Sama, Pelaporan dan Evaluasi Badan Usaha Milik Daerah, Undang-Undang Nomor 1 Tahun 2014 tentang Perbendaharaan Negara, Undang-Undang Nomor 23 Tahun 2014 tentang Pemerintahan Daerah, dan Peraturan Pemerintah Nomor 27 Tahun 2014 yang saat ini telah dirubah dalam PP 28 Tahun 2020 tentang Pengelolaan Barang Milik Negara/ Daerah.

Jika melihat uraian pembahasan pertama diatas mengenai konsep pemisahan harta kekayaan BUMD sebagai perusahaan privat yang kemudian mengadakan perjanjian dengan pihak lain dalam konteks hubungan busines to busines, maka seolah-olah modal yang masuk kedalam Badan Usaha Milik Daerah sepenuhnya dapat dikuasai dan dipergunakan untuk kepentingan perusahaan oleh Organ Perusahaan, sehingga dalam pengambil keputusan tentang penyertaanm modal kepada BUMD dalam bentuk barang/ aset daerah harus dilakukan secara cermat, terukur dengan berpegang teguh pada good corporate governance.

Bagi BUMD dengan bentuk Perseoran Terbatas, tunduk dengan Undang-Undang Nomor 40 Tahun 2007 tentang Perseroan Terbatas. Dimana Badan Hukum Perusahaan diwakili oleh Direksi sebagai organ perusahaan yang bertanggungjawab atas operasional yang menjalankan perusahaan sehati-hari. Direksi memiliki pertanggungjawaban secara terbatas. 
M. Y ahya Harahap, 17 "pertanggungjawaban terbatas" sebagaimana Pasal 3 ayat (1) Undang- Undang Nomor 40 Tahun 2007 tentang Perseroan Terbatas, dinyatakan bahwa perseroan tidak bertanggung jawab terhadap utang pemegang saham (not liable of its shareholders) sebaliknya pemegang saham tidak bertanggung jawab terhadap utang perseroan; kerugian yang ditanggung pemegang saham hanya terbatas harga saham yang mereka investasikan (their lose limited to their invesment); pemegang saham, tidak bertanggung jawab lebih lanjut kepada kreditor perseroan atas aset pribadinya. Namun hal itu tidak mengurangi kemungkinan pemegang saham bertanggung jawab sampai meliputi harta pribadinya, apabila dia secara itikad buruk (bad faith) memperalat perseroan untuk kepentingan pribadi, atau pemegang saham bertindak sebagai borgtoch terhadap kreditor atas utang perseroan.

Namun dalam Pasal lain disebutkan bahwa tanggungjawab Direksi secara terbatas akan hapus dengan catatan:

a. Persyaratan Perseroan sebagai badan hukum belum atau tidak terpenuhi;

b. Pemegang saham yang bersangkutan baik langsung maupun tidak langsung dengan itikad buruk memanfaatkan Perseroan untuk kepentingan pribadi;

c. Pemegang saham yang bersangkutan terlibat dalam perbuatan melawan hukum yang dilakukan oleh Perseroan; atau

d. Pemegang saham yang bersangkutan baik langsung maupun tidak langsung secara melawan hukum menggunakan kekayaan Perseroan, yang mengakibatkan kekayaan Perseroan menjadi tidak cukup untuk melunasi utang Perseroan.

Uraian Pasal diatas, membuka tabir pertanggungjawaban terbatas yang dimiliki Direksi dalam menjalankan kewenangannya dalam suatu perseoran. Hal tersebut tidak hanya pertanggungjawaban dalam asepek keperdataam saja, melainkan aspek hukum publik seperti pertanggungjawaban pidana. Pertanyaan lain yang akan muncul dalam perspektif pengelolaah BUMD yang notabene modalnya merupakan kekayaan negara yang dipisahkan adalah, apakah jika BUMD mengalami kerugian merupakan bagian dari kerugian daerah? pertanyaan tersebut dapat dijawab dengan Peraturan Daerah yang menjelaskan kedudukan/presentasi dividen yang akan diterima oleh Pemerintah Daerah. Dividen yang diterima oleh Pemerintah Daerah dari BUMD tersebut merupakan pendapatan/penerimaan Daerah yang berasal dari penerimaan negara bukan pajak, dan masuk dalam Anggaran Pendapatan Belanja Daerah. Secara logis, jika keuntungan perusahaan berkurang, maka dividen/peluang penerimaan dividen oleh Pemerintah Daerah akan berkurang. Disitulah letak potensi kerugian daerah yang ditimbulkan apabila Direksi melakukan kesalahan sebagaimana yang disebutkan oleh Pasal 3 diatas.

Dalam suatu perjanjian antara orang dengan orang lain ataupun badan hukum yang satu dengan badan hukum yang lain, 
tidak sepenuhnya masuk dalam ranah privat tanpa turut campur hukum publik, Pasal 1320 dan 1338 yang mensyaratkan syarat sah suatu perjanjian dan kebebasan berkontrak menunjukkan bahwa dalam klasula yang halal sebagaimana disebutkan syarat perjanjian ketiga dalam Pasal 1320 indikatornya adalah klausula tersebut tidak bertentangan dengan undang-undang, ketertiban umum dan kesusilaan, hal tersebut menunjukkan bahwa ranah hukum publik dalam peristiwa perjanjian tidak dapat dilepaskan atau dikesampingkan, sehingga siapapun tunduk pada standar undang-undang/hukum positif terhadap menentukan obyek perjanjian sudah benar atau tidak.

Sebagai contoh bukti konkret dalam penjelasan diatas adalah dalam praktik perlindungan konsumen sebagaimana diatur dalam Undang-Undang Nomor 8 Tahun 199 tentang Perlindungan Konsumen, Pasal 18 menyebutkan kriteria klausula yang dilarang dalam perikatan antara konsumen dengan pelaku usaha, artinya sekalipun para pihak diberikan kebebasan menentukan isi dan bentuk perjanjian, merupakan sebuah keniscayaan menjadi tanpa campur tangan hukum publik terhadap isi perjanjian tersebut, kecuali para pihak menghendaki perikatan tersebut menjadi perikatan tidak sempurna (naturlijk verbintenis).

Dalam kasus pengagunan benda yang sebelumnya milik daerah dan menjadi penyertaan modal kepada BUMD, telah diatur dalam Peraturan Mendagri Nomor 19 Tahun
2016 tentang Pedoman Pengelolaan Barang Milik Daerah disebutkan dalam Pasal 1 angka 44 tentang ketentuan umum "penyertaan modal pemerintah daerah adalah pengalihan kepemilikan barang milik daerah yang semula merupakan kekayaan yang tidak dipisahkan menjadi kekayaan yang dpisahkan untuk diperhitungkan sebagai modal/saham daerah pada Badan Usaha Milik Negara dan Badan Usaha Milik Daerah, atau Badan Hukum lainnya yang dimiliki Negara.

Jika merujuk pasal diatas, bahwa penyertaan modal yang dilakukan oleh Pemerintah Daerah kepada BUMD sebagai suatu usaha mengalihkan atau bahkan menghapuskan barang milik daerah dari daftar aset daerah. Jika dalam perjalanan Direksi menjalankan kegiatan usaha tidak dengan prinsip Good Corporate Governence dan mengagunkan barang tersebut yang dapat sewaktu-waktu dilakukan lelang oleh pihak ketiga, maka pemerintah sebagai pemilik saham akan sulit mengambil kembali barang tersebut dengan alasan telah menjadi milik BUMD. Namun salah satu solusi adalah Pemerintah Daerah dapat mengajukan gugatan perbuatan melawan hukum terhadap BUMD kepada Pengadilan dengan dasar bahwa perjanjian tersebut dapat merugikan pemerintah daerah sebagai pemilik saham. Kecuali dalam proses pengagunan tersebut telah disetujui oleh Pemerintah Daerah dalam mekanisme Rapat Umum Pemegang Saham, maka pengajuan gugatan tidak dapat dilakukan karena telah bersesuaian dengen 
ketentuan Pasal 102 Undang-Undang Nomor 40 Tahun 2007 tentang Perseroan Terbatas.

\section{PENUTUP}

Berdasarkan uraian pembahasan diatas, maka dapat ditarik kesimpulan bahwa penyertaan modal dalam bentuk barang dari Pemerintah Daerah kepada Badan usaha Milik Daerah adalah sah sepanjang diatur dalam Peraturan Daerah dan disetujui oleh Kepala Daerah selaku Pemegang saham dan Rapat Umum Pemegang Saham, sehingga pada saat penyertaan modal yang dilakukan dalam bentuk barang milik daerah maka berdasarkan Peraturan Mendagri Nomor 19 Tahun 2016 tentang Pedoman Pengelolaan Barang Milik Daerah yang menyatakan bahwa penyertaan tersebut berarti melepaskan status barang milik daerah kepada modal BUMD, sehingga Pemerintah Daerah melalui Kepala Daerah harus tetap berpegang pada prinsip good corporate governance dan jika diketahui atau dinilai dalam perjanjian pengagunan modal BUMD yang berasal dari barang milik daerah berpotensi merugikan daerah sebagai pemegang saham, maka Kepala Daerah dapat menggunakan segala kewenangannya berdasarkan peraturan perundang-undangan dan mekanisme RUPS untuk tidak melakukan perjanjian kerjasama tersebut, karena Kepala Daerah sebagai pengelola keuangan daerah yang didalamnya terdapat barang milik daerah akan kesulitan mengambil kembali aset daerah yang telah diagunkan dalam perjanjian dengan pihak ketiga terlebih dengan sepersetujuan Kepala Daerah dalam RUPS.

\section{DAFTAR PUSTAKA}

\section{Buku}

Budiono, Herlien. Asas Keseimbangan bagi Hikum Perjanjian Indonesia (Hukum Perjanjian Berlandaskan Asas-Asas

Wigati Indonesia). Bandung: PT. Citra Aditya Bakti, 2015.

Harahap, M. Yahya. Hukum Perseroan

Terbatas. Jakarta: Sinar Grafika, 2009. Khairandy, Ridwan. Pokok-Pokok Hukum Dagang Indonesia. Yogyakarta: FH UII Press, 2014 Hukum Perseoran Terbatas.

Yogyakarta: FH UII Press, 2014 . Hukum Kontrak Indonesia Dalam Perspektif Perbandingan (Bagian Pertama). Yogyakarta: FH UII Press, 2013

Manan, Bagir. Politik Perundang-undangan Dalam Rangka Mengantisipasi Liberalisasi Perekonomian. Bandar Lampung: Fakultas Hukum UNILA.

Nugraha, Safri. Privatisasi BUMD Dalam Upaya Meningkatkan Kinerja. Jakarta: BPHN- Departemen Kehakiman, 1996. 
Fitrahady, Zuhairi, Riadhussyah, Recovery Aset Daerah yang Dijadikan Agunan oleh Pihak ...

\section{Disertasi}

Ismail, Tjip. "Implementasi Otonomi

Daerah Terhadap Paradigma Pajak

Daerah di Indonesia", Desertasi Program Pascasarjana Doktor Ilmu Hukum. Jakarta: Universitas Indonesia, 2005.

\section{Jurnal/Artikel}

Cahyaningrum, Dian. Implikasi Bentuk Hukum BUMD terhadap Pengelolaan BUMD. Jurnal Negara Hukum Vol. 9 , No. 1, (Juni 2018)

Azre, J Ilham Aldelano. Analisis Good Corporate Governance (GCG) Pada Badan Usaha Milik Daerah (BUMD) Provinsi Sumatera Barat (Studi Kasus PT Grafika Jaya Sumbar), AKP (Jurnal Administrasi dan Kebijakan Publik) Vol. II No. 3, (April 2017)

Mustafida, Latifa. Penerapan "Doktrin Misbruik Van Omstandigheiden terhadap Pembatalan Akta Notaris Berdasarkan Putusan Pengadilan". Jurnal Lex Renaissance Vol. 2, No. 1, (Januari 2017)

Yani, Teuku Ahmad. "Peran Badan Usaha Milik Daerah Dalam Meningkatkan Kesejahteraan Masyarakat (Studi Pembentukan Perusahaan Daerah di Aceh)". Kanun Jurnal Ilmu Hukum No 56, (April 2012)

\section{Peraturan Perundang-Undangan}

Kitab Undang-Undang Hukum Perdata

Undang-Undang Nomor 20 Tahun 2001 tentang Perubahan atas UndangUndang Nomor 30 Tahun 199 tentang Tindak Pidana Korupsi

Undang-Undang Nomor 19 Tahun 2003 tentang Badan Usaha Milik Negara

Undang-Undang Nomor 40 Tahun 2007 tentang Perseoran terbatas

Undang-Undang Nomor 1 Tahun 2014 tentang Perbendaharaan Negara

Undang-Undang Nomor 23 Tahun 2014 tentang Pemerintahan Daerah

Peraturan Pemerintah Nomor 54 Tahun 2017 tentang Badan usaha Milik Daerah

Peraturan Menteri Dalam Negeri Nomor 37 Tahun 2018 tentang Pengangkatan dan Pemberhentian Direksi dan Dewan Pengawas Badan Usaha Milik Daerah. Peraturan Mendagri Nomor 19 Tahun 2016 tentang Pedoman Pengelolaan Barang Milik Daerah

Peraturan Daerah Nomor 7 Tahun 2010 tentang Perubahan Bentuk Badan Hukum (PD) Patut Patuh Patju Menjadi Perseroan Terbatas (Pt) Patut Patuh Patju

Peraturan Daerah Nomor 8 Tahun 2010 tentang Penyertaan Modal Pemerintah Kabupaten Lombok Barat Kepada Badan Usaha Milik Daerah Dan Badan Hukum Lainnya

\section{Internet}

Hukum Online. "Kekayaan BUMN Bukan Bagian Keuangan Negara". https:// www.hukumonline.com/berita/baca/ 1t50913e5b4d3a1/kekayaan-bumn- 
bukan-bagian-keuangan-negara.

Diakses 31 Oktober 2012 net/2019/03/26/kasus-lcc-makinterang/. Diakses 26 maret 2019

Lombok Post Online. "Kasus LCC semakin terang". https://www.lombokpost. 